\title{
Potato Late Blight in the Columbia Basin: An Economic Analysis of the 1995 Epidemic
}

\author{
D. A. Johnson and T. F. Cummings, Department of Plant Pathology, Washington State University, Pullman 99164- \\ 6430; P. B. Hamm, Department of Botany and Plant Pathology, Hermiston Agricultural Research and Extension \\ Center, Oregon State University, Hermiston 97838; R. C. Rowe, Department of Plant Pathology, Ohio State Uni- \\ versity, Wooster 44691; J. S. Miller, Department of Plant Pathology, Washington State University; R. E. Thornton, \\ Department of Horticulture, Washington State University; G. Q. Pelter, Washington State University, Ephrata \\ 98823; and E. J. Sorensen, Washington State University, Pasco 99301
}

\begin{abstract}
Johnson, D. A., Cummings, T. F., Hamm, P. B., Rowe, R. C., Miller, J. S., Thornton, R. E., Pelter, G. Q., and Sorensen, E. J. 1997. Potato late blight in the Columbia Basin: An economic analysis of the 1995 epidemic. Plant Dis. 81:103-106.

The cost of managing late blight in potatoes during a severe epidemic caused by new, aggressive strains of Phytophthora infestans in the Columbia Basin of Washington and Oregon in 1995 was documented. The mean number of fungicide applications per field varied from 5.1 to 6.3 for early- and midseason potatoes, and from 8.2 to 12.3 for late-season potatoes in the northern and southern Columbia Basin, respectively. In 1994, a year when late blight was not severe, the mean number of fungicide applications per field made to early- and midseason potatoes was 2.0; whereas late-season potatoes received a mean of 2.5 applications. The mean per acre cost of individual fungicides applied varied from $\$ 4.90$ for copper hydroxide to $\$ 36.00$ for propamocarb + chlorothalonil. Total per acre expenses (application costs plus fungicide material) for protecting the crop from late blight during 1995 ranged from $\$ 106.77$ to $\$ 110.08$ for early and midseason potatoes in different regions of the Columbia Basin and from $\$ 149.30$ to $\$ 226.75$ for lateseason potatoes in the northern and southern Columbia Basin, respectively. Approximately 28\% of the crop was chemically desiccated before harvest as a disease management practice for the first time in 1995, resulting in an additional mean cost of $\$ 34.48 /$ acre or $\$ 1.3$ million for the region. Harvested yields were 4 to $6 \%$ less than in 1994. The total cost of managing late blight in the Columbia Basin in 1995 is estimated to have approached \$30 million.
\end{abstract}

The Columbia Basin in Washington and Oregon is a major potato (Solanum tuberosum L.) growing area in North America. This semiarid region produces $20 \%$ of the U.S. potato crop. Outbreaks of potato late blight, caused by Phytophthora infestans (Mont.) de Bary, have occurred regularly in irrigated fields in the Columbia Basin since 1990. The severity of these outbreaks has varied from only 250 ha $(618$ a) affected in 1990 to more than 15,000 ha $(37,000$ a) in 1991 to 1993 , and 769 ha (1,900 a) in 1994. Late blight was found throughout the entire region in 1995 and affected 65,000 ha (160,000 a) (19).

Before 1990, late blight was not considered a serious threat to irrigated potatoes in this region even though the disease occurred during 7 of 16 years between 1974

Corresponding author: D. A. Johnson

E-mail: DJOHNSN@wsu.edu

Accepted for publication 9 October 1996.

Publication no. D-1996-1118-04S

(C) 1997 The American Phytopathological Society and 1989 (10) and was a factor under irrigation in a similar environment in Israel $(16,17)$. Many factors may have contributed to the recent outbreaks in the Columbia Basin. These include abundant inoculum in early spring from overwintering sources, an aggressive population of $P$. infestans $(13,14)$, higher than normal precipitation (10), widespread use of overhead sprinkler irrigation (9), early plantings of very susceptible cultivars such as Shepody and Russet Norkotah (8), and an increased proportion of the $P$. infestans population insensitive to the fungicide metalaxyl $(1,4,6)$.

The total cost of growing potatoes in the Columbia Basin prior to the severe epidemic of late blight in 1995 was estimated to be $\$ 4,949$ to $\$ 6,180 /$ ha $(\$ 2,000$ to $\$ 2,500 / a)$ (Washington Potato Commission, unpublished). As a result of the increased prevalence of late blight and associated management expenses, the cost of cultivating potatoes in the Pacific Northwest has increased. The purpose of this study was to document the costs associated with managing a severe epidemic of late blight caused by new, aggressive strains of P. infestans in the Columbia Basin in 1995.

\section{MATERIALS AND METHODS}

The Columbia Basin was divided into three geographical regions: the north and south basin in Washington and the basin in Oregon (Fig. 1). The epidemic was most severe in the south basin of Washington and in Oregon. The disease was first observed on 6 June 1995 in Oregon. It was less severe in the north basin, where the potato crop emerged later and the epidemic began approximately 4 weeks later. Because management resources expended on long-season, late-harvested potatoes exceeded those expended on short-season, earlier harvested potatoes, the potato crop was also further partitioned according to time of harvest. Potatoes harvested in July or August, classed as early- to midseason, consisted primarily of the cultivars Russet Norkotah, Shepody, and Ranger Russet. Potatoes harvested in September and beyond, classed as late-season, were nearly all of the Russet Burbank cultivar. The US8 genotype of $P$. infestans was dominant in the Columbia Basin in 1995 (13).

During the winter of 1996, owners or managers of 41 potato-growing operations in Washington were interviewed in person or by telephone and asked a set of questions to determine the expenses incurred for management of late blight in 1995 . These operations accounted for 13,841 ha $(34,260$ a) or $26 \%$ of the potato production in the Columbia Basin of Washington and were representative of the management practices in the region. Survey questions addressed the number and method of late blight fungicide applications (the application method used [including agricultural airplane sprayer], chemigation through sprinkler irrigation system, and ground sprayer costs); the cost of fungicide (the type, cost, and rate of fungicide used); the cost of foliage desiccation; and whether this was the first year foliage was chemically killed before harvest. Late blight management records for growers in Oregon were collected from individual chemical dealerships that represented all the potato production of 10,800 ha $(26,700 \mathrm{a})$ in the Columbia Basin of Oregon. The number 
of fungicide applications per field and the mean cost of applications and fungicide materials for Oregon were determined.

Late blight management costs in 1995 were compared with those in 1994 , when the disease was much less severe, to give an indication of disease management costs before 1995. Costs of fungicides and applications and number of applications for managing late blight in 1994 were determined by interviewing four potato field managers representing 4,595 ha (11,375 a) or $9 \%$ of the potato production in Washington's Columbia Basin.

Six Columbia Basin processors held harvested potatoes in long-term storage in 1995 to 1996. Representatives from four of these processors were interviewed to determine the extent and cost of losses in storage. These processors represented $95 \%$ of the stored potatoes used in processing.

Economic data are reported as dollars per acre, and this can be converted to dollars per hectare by multiplying figures by 2.471 .

\section{RESULTS}

The number of fungicide applications made in 1995 to early- and midseason potatoes ranged from 5.1 to 6.3 (Table 1). In Washington, the number of applications on late-season potatoes ranged from 8.2 in the north basin to 12.3 in the south basin (Table 2). Number of fungicide applications refers to the number of fungicide application operations performed. Because mixtures of late blight fungicides were sometimes used, more than one late blight

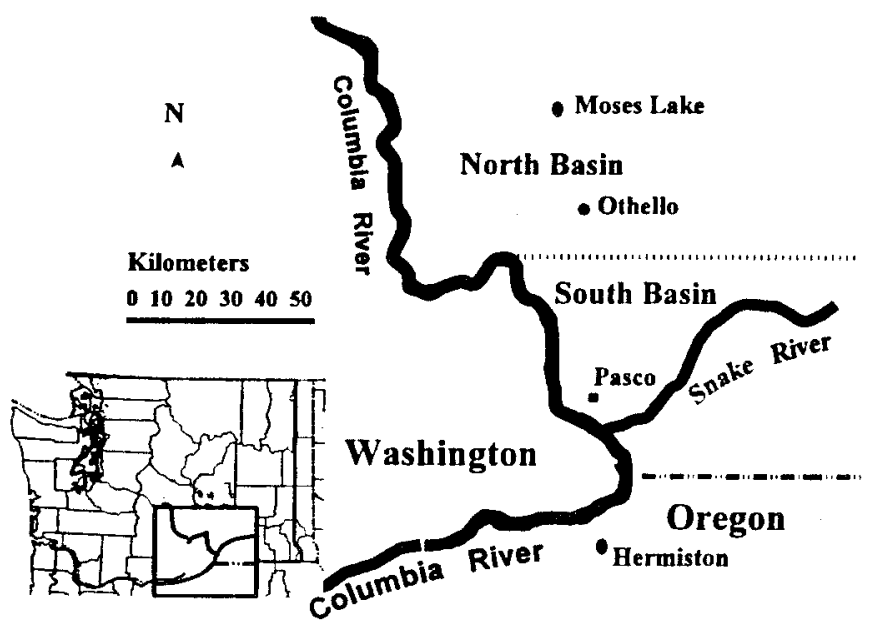

Fig. 1. Map of the potato production area in the Columbia Basin of Washington and Oregon (insert) showing the north and south basin of Washington and the basin of Oregon.

Table 1. Number of fungicide applications and cost of applications and materials for management of late blight on early- to midseason potatoes in three areas in the Columbia Basin of Washington and Oregon in 1995

\begin{tabular}{|c|c|c|c|c|}
\hline & \multicolumn{3}{|c|}{ Washington } & \multirow{2}{*}{$\begin{array}{c}\text { Oregon } \\
\text { south basin }\end{array}$} \\
\hline & North basin & South basin & Avg. & \\
\hline \multicolumn{5}{|c|}{ Number of fungicide applications per field ${ }^{a}$} \\
\hline Mean & 5.1 & 5.2 & 5.2 & 6.3 \\
\hline Standard error & 0.69 & 0.97 & 0.54 & 0.50 \\
\hline Range & $3-9$ & $2-7$ & $2-9$ & $4-10$ \\
\hline Sample size & 8 & 5 & 13 & 15 \\
\hline \multicolumn{5}{|c|}{ Total application cost per acre $(\$)^{\mathrm{b}}$} \\
\hline Mean & 35.50 & 32.20 & 34.23 & 37.98 \\
\hline Standard error & 4.61 & 5.75 & 3.48 & $\ldots$ \\
\hline Range & $21-63$ & $14-46$ & $14-63$ & $\ldots$ \\
\hline Sample size & 8 & 5 & 13 & $\ldots$ \\
\hline \multicolumn{5}{|c|}{ Fungicide cost per acre $(\$)$} \\
\hline Mean & 71.77 & 74.57 & 72.85 & 72.10 \\
\hline Standard error & 12.97 & 29.37 & 13.08 & $\ldots$ \\
\hline Range & $23-133$ & $18-169$ & $18-169$ & $\ldots$ \\
\hline Sample size & 8 & 5 & 13 & $\ldots$ \\
\hline \multicolumn{5}{|c|}{ Application and total fungicide cost per acre (\$) } \\
\hline Mean & 107.27 & 106.77 & 107.08 & 110.08 \\
\hline Standard error & 14.96 & 34.67 & 15.31 & $\ldots$ \\
\hline Range & $44-175$ & $32-215$ & $32-215$ & $\ldots$ \\
\hline Sample size & 8 & 5 & 13 & $\ldots$ \\
\hline
\end{tabular}

a More than one fungicide may be present in an application.

${ }^{\mathrm{b}}$ Costs based on application method: air $=\$ 7.00 / \mathrm{a}$, chemigation $=\$ 3.50 / \mathrm{a}$.

fungicide may have been applied during a single application. In Washington, $75 \%$ of the applications were made by air and $25 \%$ by chemigation through center-pivot sprinkler irrigation systems.

Cost of applications and fungicides for early- to midseason potatoes ranged from $\$ 106.77$ to $\$ 110.08$ in the three regions (Table 1). Cost of applications and fungicides for late-season potatoes ranged from $\$ 149.30$ to $\$ 226.75$ (Table 2).

The costs and use patterns of the specific late blight fungicides used in Washington are shown in Table 3. The cost of fungicides per acre varied from $\$ 4.90$ for copper hydroxide to an average of $\$ 28.70$ for the section 18 materials (Crisis Exemption materials approved by the Environmental Protection Agency for 1995: propamocarb + chlorothalonil, dimethomorph + mancozeb, and cymoxanil + mancozeb). Chlorothalonil and ethylene bis-dithiocarbamate (EBDC) fungicides were most frequently used and accounted for 36 and $23 \%$, respectively, of the fungicides applied. The section 18 materials and metalaxyl mixtures had the highest cost per application (Table 3).

In 1994, the mean number of fungicide applications per field was 2.0 and the mean cost for applications and fungicides was $\$ 26.00 / \mathrm{a}$ for early- to midseason potatoes. For late-season potatoes, the mean number of applications was 2.5 and the mean cost of applications and fungicides was \$47.53/a.

More than $95 \%$ of the potato crop was chemically killed in 1995, while in 1994 approximately $67 \%$ of Washington's potato crop was vine killed. In Washington, vine killing costs (desiccant and application) averaged \$34.48/a and ranged from $\$ 21.09 / \mathrm{a}$ to $\$ 50.89 / \mathrm{a}$. All late russet potatoes grown in Oregon's Columbia Basin were vine killed in both 1995 and 1994. None of the early- to midseason potatoes were vine killed in Oregon in 1994.

Processors from the north basin of Washington reported no significant direct storage losses associated with late blight. However, because of the potential of placing infected tubers in storage, additional labor was required for field inspections before harvest, sorting at harvest, and additional inspections of tubers in storage. Estimates of these additional costs beyond that of managing other storage diseases were not provided by Washington processors, but were acknowledged as significant. A storage facility from the southern $\mathrm{Co}$ lumbia Basin reported a 7 to $8 \%$ loss on 10,000 tons of tubers due to late blight in storage, but this was an atypical situation. Processors from Oregon's southern basin reported an increased processing cost in 1995 of approximately $\$ 2,965,000$ associated with late blight, mostly on late-season Russet Burbank. This additional cost included actual losses from storage, replacement costs of raw product, additional 
labor costs involved with sorting tubers going into and out of storage, and storage inspections.

\section{DISCUSSION}

The importance of quantifying the effect of plant pathogens on crop yields and documenting the cost of managing disease in a crop has often been recognized $(3,11,12,15)$. However, since obtaining reliable data on crop loss is difficult $(2,11,12)$, costs of disease epidemics are rarely estimated accurately. The cost of disease management is categorized as a direct loss $(11,15)$, and knowing the cost of management practices is important for development and selection of economically viable disease management strategies (15).

Since 1993, aggressive strains of $P$. infestans have migrated into the Columbia Basin $(6,13,14)$ and are more difficult to manage than older strains (5). The late blight epidemic on potatoes in the Columbia Basin in 1995 presented an opportunity to document the cost of managing a severe epidemic of late blight and to make comparisons with the previous year when the disease was much less severe.

The severe effect of late blight on the Columbia Basin potato industry in 1995 was reflected in the large increase in the number of fungicide applications compared with 1994 and the high mean total application and fungicide costs (Tables 1 and 2). All regions showed an increase of more than $\$ 80 /$ a for early- to midseason potatoes and approximately $\$ 100 / \mathrm{a}$ to $\$ 180 / \mathrm{a}$ for late-season potatoes. Management costs were higher in the Washington south basin and in Oregon, which reflected the early development of late blight. Because the average Columbia Basin potato field is $\mathbf{1 2 5}$ acres, the total per field cost for fungicides and applications on late-season potatoes in 1995 ranged from approximately $\$ 18,700$ to $\$ 28,300$. These data confirm that the impact of late blight management on total production costs for the Columbia Basin potato industry was substantial, especially since over $60 \%$ of the potato crop there consists of late-season russets (Washington Potato Commission, unpublished).

Effective management of late blight requires early, consistent, and thorough application of efficacious fungicides. Initial fungicide applications in the Columbia Basin are based on late blight forecasting models (10). Subsequent applications are determined by weather forecasts, disease levels, and irrigation frequency. Once potato plants are infected after row closure, microclimatic conditions are generally favorable for continued disease development whenever the field is irrigated (9). The selection and cost of individual fungicides can become a critical financial decision for successful potato production during a late blight epidemic. The protectant fungicides, chlorothalonil and EBDCs, were the major fungicides used to control late blight in the Columbia Basin in 1995 (Table 3). Costs of these protectants and the less expensive copper (copper hydroxide) or tin (triphenyltin hydroxide) fungicides ranged from $\$ 5.00 / \mathrm{a}$ to $\$ 9.00 / \mathrm{a}$. Tin fungicides were mainly used in mixtures with metiram. The section 18 materials and metalaxyl mixtures were applied 8.5 and $7.0 \%$ of the time, respectively, but constituted 23.8 and $17.8 \%$, respectively, of the total cost of fungicides applied in the basin in 1995 (Table 3).

It is doubtful that there is a cost-effective benefit in the use of the expensive metalaxyl mixtures in late blight management, since the strains of $P$. infestans identified in the Columbia Basin in 1995 all had some insensitivity to metalaxyl (13). Furthermore, multiple applications of protectant fungicides were made at less cost than a single application of any one section 18 material. Hence, the expensive section 18 fungicides may not be cost-effective when compared with early, consistent, and thorough applications of protectant fungicides that have been shown to be effective against the disease in experimental field plots (7). However, at this time there is no consensus on the relative effectiveness of these section 18 materials compared with protectant fungicides when used under commercial potato production conditions.

An added cost for late blight management in 1995 was the chemical desiccation of potato foliage. Although in recent years, more processors have encouraged chemical vine killing for improved processing quality, before 1995 not all potato vines were desiccated prior to harvest. Usually vines of direct processed and fresh market potatoes are not killed with desiccants. In 1994, approximately two-thirds of the potato crop in the Columbia Basin was vine killed, while in 1995 nearly all potatoes for storage were artificially vine killed before harvest. Vine kill at least 2 weeks before harvest is a useful practice to reduce the potential of tuber infections in potatoes

Table 2. Number of fungicide applications and cost of applications and materials for management of late blight on late-harvested potatoes in three areas in the Columbia Basin of Washington and Oregon in 1995

\begin{tabular}{|c|c|c|c|c|}
\hline & \multicolumn{3}{|c|}{ Washington } & \multirow{2}{*}{$\begin{array}{c}\text { Oregon } \\
\text { south basir }\end{array}$} \\
\hline & North basin & South basin & Avg. & \\
\hline \multicolumn{5}{|c|}{ Number of fungicide applications per field ${ }^{a}$} \\
\hline Mean & 8.2 & 12.3 & 10.0 & 9.4 \\
\hline Standard error & 0.52 & 1.05 & 0.66 & 0.46 \\
\hline Range & $6-13$ & $7-18$ & $6-18$ & $6-15$ \\
\hline Sample size & 16 & 12 & 28 & 23 \\
\hline \multicolumn{5}{|c|}{ Total application cost per acre $(\$)^{\mathrm{b}}$} \\
\hline Mean & 56.24 & 70.42 & 62.38 & 56.10 \\
\hline Standard error & 4.17 & 3.91 & 3.16 & $\ldots$ \\
\hline Range & $22-91$ & $46-88$ & $22-91$ & $\ldots$ \\
\hline Sample size & 16 & 12 & 28 & $\ldots$ \\
\hline \multicolumn{5}{|c|}{ Fungicide cost per acre $(\$)$} \\
\hline Mean & 92.96 & 156.34 & 120.12 & 123.18 \\
\hline Standard error & 7.73 & 16.27 & 10.08 & $\ldots$ \\
\hline Range & $37-154$ & $53-234$ & $37-234$ & $\ldots$ \\
\hline Sample size & 16 & 12 & 28 & $\ldots$ \\
\hline \multicolumn{5}{|c|}{ Total application and fungicide cost per acre (\$) } \\
\hline Mean & 149.30 & 226.75 & 182.49 & 179.28 \\
\hline Standard error & 10.49 & 18.91 & 12.32 & $\ldots$ \\
\hline Range & $59-215$ & $102-321$ & $59-321$ & $\ldots$ \\
\hline Sample size & 16 & 12 & 28 & $\ldots$ \\
\hline
\end{tabular}

${ }^{a}$ More than one fungicide may be present in an application.

${ }^{\mathrm{b}}$ Costs based on application method: $\mathrm{air}=\$ 7.00 / \mathrm{a}$, chemigation $=\$ 3.50 / \mathrm{a}$.

Table 3. Number of applications and costs for specific late blight fungicides applied to 40 potato fields in the Columbia Basin of Washington during 1995

\begin{tabular}{|c|c|c|c|c|c|c|}
\hline & $\begin{array}{l}\text { Chloro- } \\
\text { thalonil }\end{array}$ & EBDC $^{\mathbf{a}}$ & Copper $^{\mathrm{b}}$ & $\operatorname{Tin}^{\mathrm{c}}$ & $\begin{array}{c}\text { Sect. 18 } \\
\text { materials }^{\mathbf{d}}\end{array}$ & $\begin{array}{l}\text { Metalaxyl } \\
\text { mixtures }\end{array}$ \\
\hline No. treatments $\mathrm{N}=400^{\mathrm{f}}$ & 143 & 91 & 62 & 42 & 34 & 28 \\
\hline Percent total applications & 35.8 & 22.8 & 15.5 & 10.5 & 8.5 & 7.0 \\
\hline Percent fungicide cost & 31.2 & 13.5 & 7.4 & 6.3 & 23.8 & 17.8 \\
\hline $\begin{array}{l}\text { Avg. cost }(\$) \text { of fungicide } \\
\text { per application }\end{array}$ & 8.93 & 6.09 & 4.90 & 6.15 & 28.70 & 26.10 \\
\hline
\end{tabular}

${ }^{a}$ Ethylene bis-dithiocarbamate (maneb, mancozeb, and metiram).

${ }^{\mathrm{b}}$ Copper hydroxide.

c Triphenyltin hydroxide.

${ }^{\mathrm{d}}$ Propamocarb hydrochloride + chlorothalonil, dimethomorph + mancozeb, cymoxanil + mancozeb .

${ }^{\mathrm{e}}$ Metalaxyl + chlorothalonil, metalaxyl + mancozeb, metalaxyl + copper hydroxide

${ }^{\mathrm{f}}$ Number of treatments refers to each time a specific fungicide was applied, whether by itself or mixed with other fungicides. 
that are to be stored. Nearly $87 \%$ of the potato crop in the Columbia Basin is processed, and a high percentage of these potatoes are stored. Because of the high incidence of late blight in 1995, approximately $28 \%$ of the potato crop in Washington incurred an additional cost of over \$34.00/a for vine kill. This alone amounted to an additional production cost of approximately $\$ 1.3$ million for the region.

Potato yields in Washington and Oregon in 1995 were 6 and 4\%, respectively, less than the previous year (19). Crop yields may fluctuate from year to year for many reasons, but in the Columbia Basin there was consensus among growers, processors, consultants, and by the authors that late blight was a major factor in reducing potato yields in 1995. Lower yields did not generally result from yields in individual fields being directly affected by late blight, even though this did occur, but rather was due to the fact that preharvest vine killing was practiced nearly universally in the 1995 Columbia Basin potato crop. Chemical desiccation of potato vines can reduce yields by approximately $5 \%$ in late-season potatoes compared with a potato crop in which vines are allowed to naturally senesce (18). Early vine kill reduces the production and translocation of photosynthates from the vines to the tubers at the end of the tubers' growth cycle, reducing yields. Much of the vine kill occurred earlier in the season in 1995 than in previous years.

Placing tubers with late blight into storage can result in significant economic losses, not only because blighted tubers are unmarketable, but even more importantly, because of the associated spread of secondary pathogens in storage, primarily the soft rot Erwinia sp. Besides this direct economic loss, extra precautions taken by processors, i.e., tuber inspection, storage management, and monitoring, also contribute to significantly higher production costs. These added production costs along with tuber losses in storage due to late blight were documented in Oregon and amounted to nearly $\$ 3,000,000$. Except for a storage in the south Colombia Basin of Washing-ton, processors in Washington reported no increase in storage losses in the 1995 potato crop compared with previous years. Tubers in several individual storages had to be processed earlier than originally planned because of tuber infections. Owners of these storage facilities did not receive anticipated revenue for long-term storage.

The total cost of managing late blight in potatoes in the Columbia Basin in 1995 approached \$30 million. This cost included fungicide application and materials of $\$ 8.3$ million for the Washington north basin, $\$ 13.2$ million for the Washington south basin, and \$3.8 million for Oregon; a cost associated with additional vine kill of $\$ 1.3$ million; and storage losses of $\$ 3.0$ million in Oregon. Costs not quantified included added processor costs in Washington and economic loss from yield reduction due to additional vine kill and earlier than normal vine kill in the basin in 1995. Fungicide applications and materials in 1994, on $3 \%$ more production acreage than in 1995 , were estimated at $\$ 6.6$ million. Compared with 1994, an additional $\$ 18.7$ million was spent in 1995 on application and materials for management of potato late blight.

These data present a valid argument for improving the level of late blight resistance in potato cultivars. The use of cultivars with improved resistance would reduce the dependence on fungicides and the on-farm cost of managing the disease. Improved host resistance, disease forecasting systems to schedule fungicide applications, and strict sanitation practices are needed to economically manage potato late blight.

\section{ACKNOWLEDGMENTS}

Plant Pathology New Series No. 0238, project 0678, College of Agriculture and Home Economics Research Center, Washington State University, Pullman 99164.

\section{LITERATURE CITED}

1. Bentley, E. M., and Johnson, D. A. 1992. Late blight in central Washington. Proc. Wash. State Potato Conf., Wash. State Potato Comm., Moses Lake.

2. Calpouza, L., Roelfs, A. P., Madson, M. E., Martin, F. B., Welsh, J. R., and Wilcoxson, R. D. 1976. A new model to measure yield losses caused by stem rust in spring wheat. Tech. Bull. Agric. Exp. Stn. 397, University of Minnesota, St. Paul.

3. Cook, R. J. 1985. Use of the term "crop loss." Plant Dis. 69:95.

4. Deahl, K. L., and DeMuth, S. P. 1993. First report of resistance of Phytophthora infestans to metalaxyl in eastern Washington and southwestern British Columbia. Plant Dis. 77:429.

5. Geary, B., Johnson, D. A., and Cummings, T. 1996. Aggressiveness of Phytophthora infestans US-8 and US- 1 on potato leaflets treated with various fungicides. (Abstr.) Phytopathology 86(Suppl.):S31.

6. Hamm, P. B., Fry, B. A., and Jaeger, J. 1994 Occurrence and frequency of metalaxyl insensitivity and mating types of Phytophthora infestans in the Columbia basin of Oregon and Washington. (Abstr) Phytopathology 84:1123.

7. Inglis, D. A., Gundersen, B., Johnson, L., and Callahan, N. 1996. Effective use of late blight control fungicides. Proc. Wash. State Potato Conf., Wash. State Potato Comm., Moses Lake.

8. Inglis, D. A., Johnson, D. A., Legard, D. E., Fry, W. E., and Hamm, P. B. 1995. Relative resistances of potato clones in response to new and old populations of Phytophthora infestans. Plant Dis. 80:575-578.

9. Johnson, D. A. 1996. Using meteorological information to help manage late blight. Proc. Wash. State Potato Conf., Wash. State Potato Comm., Moses Lake.

10. Johnson, D. A., Alldredge, J. K., and Vakoch, D. L. 1996. Potato late blight forecasting models for the semi-arid environment of the south central Washington. Phytopathology 86:480-484.

11. Le Clery, E. L. 1964. Crop losses due to plant diseases in the United States. Phytopathology 54:1309-1313.

12. Madden, L. V., and Nutter, F. W., Jr. 1995. Modeling crop losses at the field scale. Can. J. Plant Pathol. 17:124-137.

13. Miller, J. S., Hamm, P. B., and Johnson, D. A. 1996. Characterization of Phytophthora infestans from the Columbia basin of Oregon and Washington from 1992-1995. (Abstr.) Phytopathology 86(Suppl.):S13.

14. Miller, J. S., Johnson, D. A., and Hamm, P. B 1995. Aggressiveness of Phytophthora infestans isolates in the Pacific Northwest. (Abstr.) Phytopathology 85:1127.

15. Nutter, F. W., Jr., Teng, P. S., and Royer, M H. 1993. Terms and concepts for yield, crop loss, and disease thresholds. Plant Dis. 77:211-215.

16. Rotem, J., and Cohen, Y. 1974. Epidemiological patterns of Phytophthora infestans under semi-arid conditions. Phytopathology 64:711714.

17. Rotem, J., Palti, J., and Lomus, J. 1970. Effects of sprinkler irrigation at various times of the day on development of potato late blight. Phytopathology 60:839-843.

18. Thornton, R. E. 1995. Vine desiccation-some considerations. Spud Topics. Vol. 41, No. 6. Wash. State Potato Comm., Moses Lake.

19. Washington Agricultural Statistics Service. 1995. Washington Agricultural Statistics. Washington State Department of Agriculture, Olympia. 